\title{
Synthesis, characterization and thermal behavior of some trivalent lanthanide 4-amino-benzenesulfonate salts
}

\author{
Fabrício Rossi Marques Matias ${ }^{1} \cdot$ Vivian Martins F. da Silva $^{1} \cdot$ Ronaldo Spezia Nunes $^{2} \cdot$ \\ José Marques Luiz ${ }^{2}$
}

Received: 16 December 2016/Accepted: 14 July 2017/Published online: 27 July 2017

(C) Akadémiai Kiadó, Budapest, Hungary 2017

\begin{abstract}
The lanthanide 4-amino-benzenesulfonate salts (or sulfanilates) were obtained by the reaction of lanthanide carbonates $\left(\mathrm{La}^{3+}, \mathrm{Ce}^{3+}, \mathrm{Pr}^{3+}, \mathrm{Nd}^{3+}, \mathrm{Sm}^{3+}, \mathrm{Eu}^{3+}\right.$ and $\mathrm{Gd}^{3+}$ ) and 4-amino-benzenesulfonic (or sulfanilic) acid in aqueous solution. Simultaneous thermogravimetry, differential thermal analysis and differential scanning calorimetry, elemental analysis, X-ray powder diffractometry and infrared spectroscopy (FTIR) were used to characterize and to study the thermal behavior of these compounds. The general formula could be established as $\mathrm{LnL}_{3} \cdot n \mathrm{H}_{2} \mathrm{O}$, where $\mathrm{Ln}$ represents trivalent lanthanide ions (La-Gd), $\mathrm{L}$ is the 4-amino-benzenesulfonate anion $\left(\mathrm{NH}_{2}\right.$ $\left.\mathrm{C}_{6} \mathrm{H}_{4} \mathrm{SO}_{3}^{-}\right)$and $n=8(\mathrm{La}-\mathrm{Gd})$ and $n=7$ only for Ce. The thermal behavior indicates that dehydration occurs in a single step up to $443 \mathrm{~K}$, characterized by an endothermic peak, and the enthalpy of dehydration was evaluated by DSC. Thermal decomposition takes place above $523 \mathrm{~K}$ producing a stable intermediate $\mathrm{Ln}_{2} \mathrm{O}_{2} \mathrm{SO}_{4}$ characterized by $\mathrm{X}$ - ray diffraction, which in the sequence decomposed to the respective oxides. For the $\mathrm{La}^{3+}, \mathrm{Nd}^{3+}$ and $\mathrm{Pr}^{3+}$ sulfanilates, the residual oxide formation occurs only after $1573 \mathrm{~K}$.
\end{abstract}

Keywords Lanthanides · Sulfanilates · 4-Aminobenzenesulfonates . Thermal behavior

José Marques Luiz

jmluiz@feg.unesp.br

1 Departamento Engenharia de Materiais e Tecnologia, Faculdade de Engenharia, Universidade Estadual Paulista (UNESP), Guaratinguetá, SP, Brazil

2 Departamento de Física e Química, Faculdade de Engenharia, Universidade Estadual Paulista (UNESP), Guaratinguetá, SP, Brazil

\section{Introduction}

The molecular formula of sulfanilic acid $(\mathrm{pKa}=3.232)$ or 4-amino-benzenesulfonic acid may be represented by $\left(\mathrm{C}_{6}\right.$ $\left.\mathrm{H}_{7} \mathrm{NO}_{3} \mathrm{~S}\right)$ or $\left(\mathrm{NH}_{2} \mathrm{C}_{6} \mathrm{H}_{4} \mathrm{SO}_{3} \mathrm{H}\right)$. It is an organic synthetic compound obtained from aniline and sulfuric acid. It is a zwitterion, in other words, a dipolar ion having opposite charges on different atoms. In the complex compound formation, the sulfonic group $\left(-\mathrm{SO}_{3}^{-}\right)$can act as a monodentate, bidentate or tridentate ligand for different metallic ions. In some cases, both the amine $\left(-\mathrm{NH}_{2}\right)$ and sulfonic groups participate in the metal coordination [1].

Rare earths are a group of metallic elements which contain, in addition to the lanthanides $\left({ }_{58} \mathrm{Ce}\right.$ to $\left.{ }_{71} \mathrm{Lu}\right)$, the elements ${ }_{21} \mathrm{Sc},{ }_{39} \mathrm{Y}$ and ${ }_{57} \mathrm{La}$ [2]. In coordination chemistry, the lanthanide ions $\left(\mathrm{Ln}^{3+}\right)$ are classified as hard acid by Pearson's theory. Among the electron donor species, namely bases, the preference to form a bond follows the $\mathrm{O}>\mathrm{N}>\mathrm{S}>\mathrm{F}$ order, with ionic nature interactions. The sulfanilate ion $\left(\mathrm{NH}_{2} \mathrm{C}_{6} \mathrm{H}_{4} \mathrm{SO}_{3}^{-}\right)$has suitable chemical characteristics to act as a ligand with lanthanide ions.

In the literature, some studies report the synthesis and the structure determination of some sulfanilates with alkali metal, ammonium and transition metals [3-11]. Gunderman [7] described the synthesis of the two complexes, bis(4-amino-benzenesulfonate)diaquocopper(II) dihydrate, $\left[\mathrm{Cu}\left(\mathrm{C}_{6} \mathrm{H}_{6} \mathrm{NO}_{3} \mathrm{~S}\right)_{2}\left(\mathrm{H}_{2} \mathrm{O}\right)_{2}\right] \cdot 2 \mathrm{H}_{2} \mathrm{O}$ and bis(4-amino-benzenesulfonate)diaquomanganese(II) $\left[\mathrm{Mn}\left(\mathrm{C}_{6} \mathrm{H}_{6} \mathrm{NO}_{3} \mathrm{~S}\right)_{2}\left(\mathrm{H}_{2} \mathrm{O}\right)_{2}\right]$. Vinciguerra et al. [8] studied the magnetic moment, infrared and optical spectra of ortho-, meta- and paraamino-benzenesulfonates of copper (II). Shakeri and Haussühl [9] studied the crystal structure of the cobalt sulfanilate tetrahydrate $\left[\mathrm{Co}\left(\mathrm{NH}_{2} \mathrm{C}_{6} \mathrm{H}_{4} \mathrm{SO}_{3}\right)_{2}\left(\mathrm{H}_{2} \mathrm{O}\right)_{4}\right]$. Zhao et al. [12] studied the structure of 4-amino-benzenesulfonates of some lanthanide metals ( $\mathrm{La}, \mathrm{Nd}, \mathrm{Sm}, \mathrm{Eu}$, 
Tb, Dy and Er) by means of FTIR and X-ray diffraction. In most of these studies, the main goal was the structure determination of the synthesized compound, and a few of them have reported the thermal behavior of the compounds derivatives from sulfonic acid.

\section{Experimental}

\section{Synthesis}

The 4-amino-benzenesulfonic acid, $\mathrm{NH}_{2} \mathrm{C}_{6} \mathrm{H}_{4} \mathrm{SO}_{3} \mathrm{H}$, with 99.6\% was obtained from Sigma. Carbonates of La(III), $\mathrm{Ce}(\mathrm{III}), \mathrm{Pr}(\mathrm{III}), \mathrm{Nd}(\mathrm{III}), \mathrm{Sm}(\mathrm{III}), \mathrm{Eu}(\mathrm{III})$ and Gd(III) were prepared by adding slowly, with continuous stirring, the saturated sodium hydrogen carbonate solution to the corresponding metal chlorides or nitrate solutions until total precipitation of the metal ions. The precipitates were washed with distilled water until the elimination of chloride or nitrate ions (qualitative test with $\mathrm{AgNO}_{3} / \mathrm{HNO}_{3}$ solution for chloride ions or diphenylamine in sulfuric acid solution for nitrate ions) and maintained in aqueous suspension.

Solid-state $\mathrm{Ln}^{3+}$ sulfanilates were prepared by mixing the aqueous solution of 4-amino-benzenesulfonic acid with the corresponding metallic carbonate suspension, in slight excess. The aqueous suspension was heated slowly up to near boiling until the total neutralization of the acid occurs. The carbonates in excess were filtered, and the aqueous solutions of the respective metallic sulfanilates were slowly evaporated. The compounds were dried in air and kept in a desiccator over anhydrous calcium chloride.

\section{Experimental equipment and conditions}

In solid-state compounds, hydration water, ligand and metal contents were determined from the TG curves. All TG, DTA and DSC curves were recorded using a SDTQ600 simultaneous TG-DTA-DSC thermal analysis controlled by Thermal Advantage (4.2.1) software, both from TA Instruments, under dynamic dry air atmosphere (gas flow of $100 \mathrm{~mL} \mathrm{~min}^{-1}$ ), heating rate of $10 \mathrm{~K} \mathrm{~min}^{-1}$ in the range of 303-1573 K, with sample masses of ca. $5 \mathrm{mg}$ in a sample holder of alumina. The dehydration enthalpy was evaluated using SDT Q600 from TA Instruments under dynamic dry air atmosphere $\left(100 \mathrm{~mL} \mathrm{~min}^{-1}\right)$, heating rate of $10 \mathrm{~K} \mathrm{~min}^{-1}$ in the range of $303-473 \mathrm{~K}$ and sample masses of ca. $4 \mathrm{mg}$ in a platinum sample holder.

Elemental analysis for $\mathrm{C}, \mathrm{H}, \mathrm{N}$ and $\mathrm{S}$ was performed using a Leco CHNS Analyzer. X-ray powder patterns were obtained using a BRUKER system D8 Advance diffractometer, employing CuK $\alpha$ radiations $(\lambda=1.54184 \AA)$ and setting of $40 \mathrm{kV}$ and $20 \mathrm{~mA}$. Each run was performed with
$2 \theta$ values between 10 and 70 at a step size of 0.010 and a count time of $0.5 \mathrm{~s}$ per step.

The attenuated total reflectance (ATR) spectra for 4-amino-benzenesulfonic acid as well as for its trivalent lanthanide compounds were run on a Spectrum system 100 ATR FTIR spectrophotometer (Perkin-Elmer), using an ATR accessory with Ge windows. The FTIR spectra were recorded with 16 scans per spectrum at a resolution of $4 \mathrm{~cm}^{-1}$.

\section{Results and discussion}

The FTIR spectra are shown in Fig. 1. The main absorption bands observed are those associated with the stretches $(v$ $\mathrm{O}-\mathrm{H}, v \mathrm{~N}-\mathrm{H}$ and $\left.v \mathrm{SO}_{3}\right)$ and deformations $(\delta \mathrm{H}-\mathrm{S}-\mathrm{H}$ and $\delta$ $\mathrm{H}-\mathrm{C}-\mathrm{H})$, and all absorptions are in agreement with Zhao et al. [12]. Significant differences are noted between the spectra of the sulfanilic acid and its compounds suggesting the complex formation. The absorption bands found between 3700 and $3000 \mathrm{~cm}^{-1}$ are related with the presence of water molecules of hydration, which are not observed in the IR spectrum of sulfanilic acid. The absorption bands of $v \mathrm{~N}-\mathrm{H}$ were not observed, associated

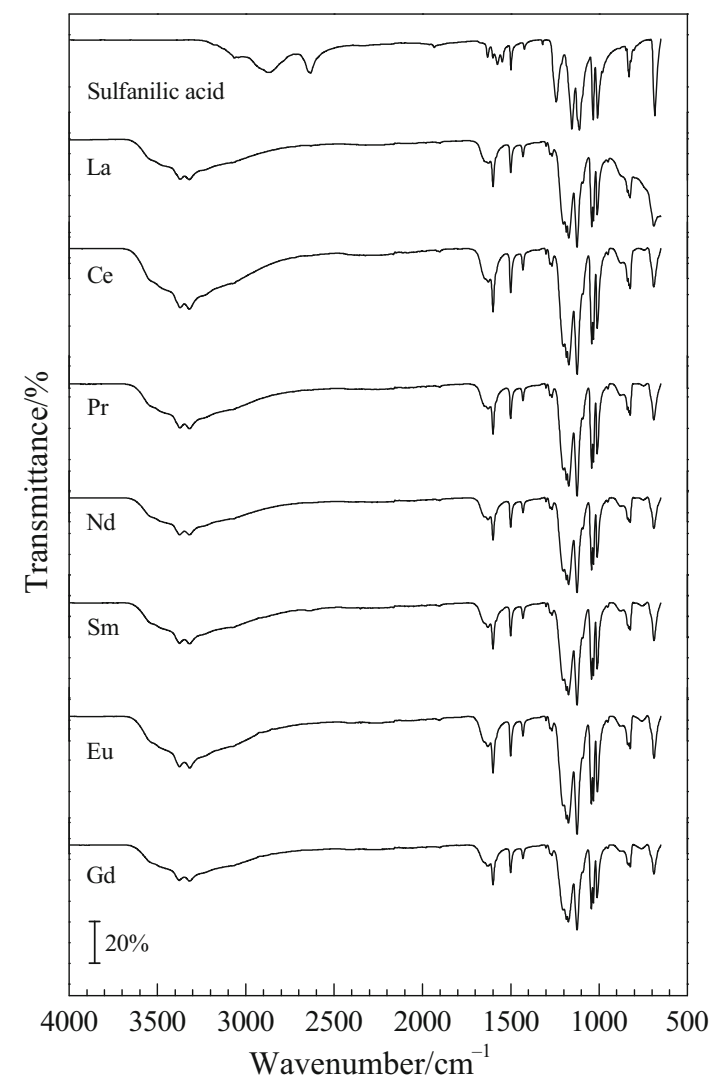

Fig. 1 FTIR spectra of the sulfanilic acid and its trivalent lanthanide compounds 
with the $-\mathrm{NH}_{2}$ group in the sulfanilic acid spectrum, while the spectra of lanthanide sulfanilates presented a broad band attributed to absorption of $\mathrm{H}_{2} \mathrm{O}$ and $-\mathrm{NH}_{2}$ $\left(1650-1631 \mathrm{~cm}^{-1}\right)$ overlapped.

The elemental analysis results are presented in Table 1 and are in agreement with the proposed general formula.

The X-ray powder patterns presented in Fig. 2 showed that all compounds were obtained with good crystallinity degree and with evidence for the formation of an isomorphic series. Zhao et al. [12] reported that in these compounds, the metallic ion is coordinated by two oxygen atoms of two sulfonate groups and seven oxygen atoms from water molecule.

The simultaneous TG-DTA curves of the compounds are shown in Fig. 3. These curves exhibit mass losses in three main steps and thermal events corresponding to these losses (endothermic and exothermic peaks). The thermal analytical data from TG curves are shown in Table 2.

The first mass loss in the range of $323-433 \mathrm{~K}$ is attributed to dehydration, which occurs in a single step with formation of anhydrous compounds (stable up to $533 \mathrm{~K}$ ). The anhydrous compounds decompose above $533 \mathrm{~K}$, and the TG curves profile suggests that the oxidation occurs at least with three overlapping events, producing $\mathrm{Ln}_{2} \mathrm{O}_{2} \mathrm{SO}_{4}$ as a stable intermediate. After this event, the stable intermediates decomposed to the respective oxides as a final residue $\left(\mathrm{La}_{2} \mathrm{O}_{3}, \mathrm{Pr}_{6} \mathrm{O}_{11}, \mathrm{Nd}_{2} \mathrm{O}_{3}, \mathrm{Sm}_{2} \mathrm{O}_{3}\right.$, $\mathrm{Eu}_{2} \mathrm{O}_{3}$ and $\mathrm{Gd}_{2} \mathrm{O}_{3}$ ). For the cerium compound, the decomposition of organic matter occurs directly to the $\mathrm{CeO}_{2}$ without the formation of the stable intermediate. These results indicate that the stability of the compounds decreases with the decreasing ionic radius of the lanthanide ions.

\section{$\mathrm{La}\left(\mathrm{NH}_{2} \mathrm{C}_{6} \mathrm{H}_{4} \mathrm{SO}_{3}\right)_{3} \cdot 8 \mathrm{H}_{2} \mathrm{O}$}

The TG-DTA curves are shown in Fig. 3a. The dehydration process occurs between 330 and $449 \mathrm{~K}$, with mass loss

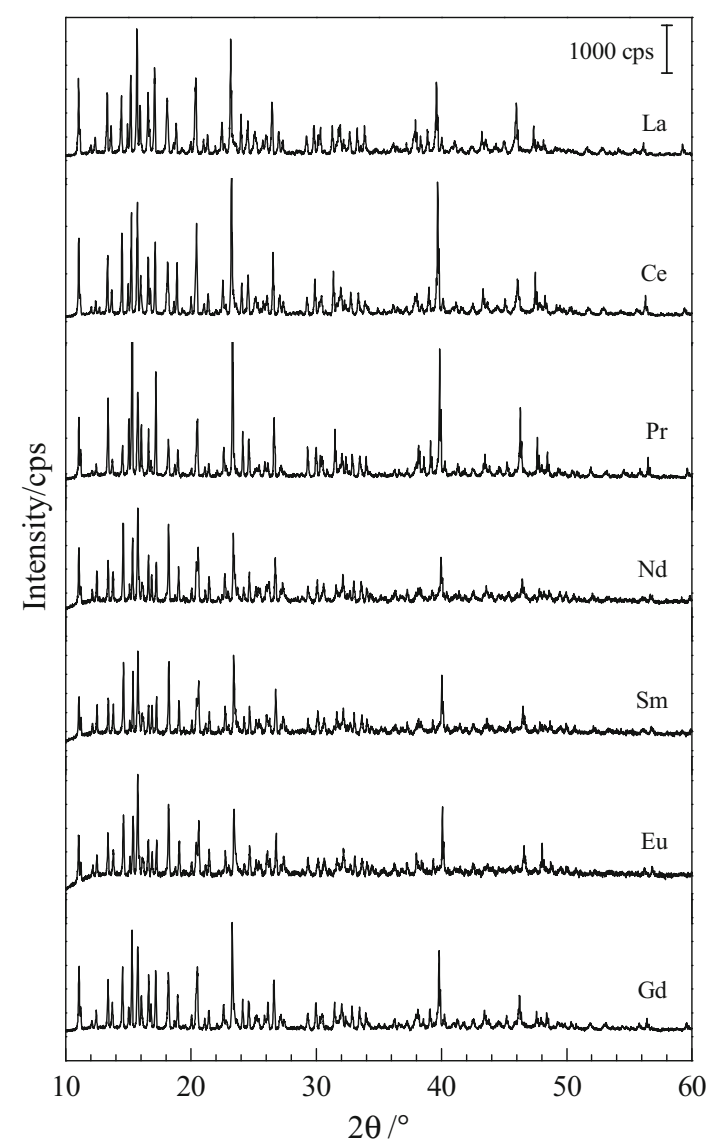

Fig. 2 X-ray diffraction pattern of the trivalent lanthanide compounds

of $18.8 \%\left(\simeq 8 \mathrm{H}_{2} \mathrm{O}\right)$ associated with an endothermic peak at $389 \mathrm{~K}$ in DTA curve. In DSC curve, this event was evaluated and an enthalpy of $539 \mathrm{~kJ} \mathrm{~mol}^{-1}$ was calculated (Fig. 4). The anhydrous compound is stable up to $529 \mathrm{~K}$ and after this temperature the thermal decomposition of organic material occurs until $1083 \mathrm{~K}$, with the formation of $\mathrm{La}_{2} \mathrm{O}_{2} \mathrm{SO}_{4}$ as stable intermediate (Fig. 3a) and X-ray diffraction patterns (Fig. 5). In these steps were observed

Table 1 Elemental analysis of the solid $\mathrm{Ln}^{3+}$ sulfanilates

\begin{tabular}{|c|c|c|c|c|c|c|c|c|}
\hline \multirow[t]{2}{*}{ Compound } & \multicolumn{2}{|l|}{$\% \mathrm{C}$} & \multicolumn{2}{|l|}{$\% \mathrm{H}$} & \multicolumn{2}{|l|}{$\% \mathrm{~N}$} & \multicolumn{2}{|l|}{$\% \mathrm{~S}$} \\
\hline & Calc. & EA & Calc. & EA & Calc. & EA & Calc. & EA \\
\hline $\mathrm{La}\left(\mathrm{NH}_{2} \mathrm{C}_{6} \mathrm{H}_{4} \mathrm{SO}_{3}\right)_{3} \cdot 8 \mathrm{H}_{2} \mathrm{O}$ & 27.17 & 28.07 & 4.30 & 4.06 & 5.26 & 5.65 & 12.03 & 12.36 \\
\hline $\mathrm{Ce}\left(\mathrm{NH}_{2} \mathrm{C}_{6} \mathrm{H}_{4} \mathrm{SO}_{3}\right)_{3} \cdot 7 \mathrm{H}_{2} \mathrm{O}$ & 27.62 & 28.34 & 4.13 & 4.08 & 5.37 & 5.59 & 12.29 & 12.83 \\
\hline $\operatorname{Pr}\left(\mathrm{NH}_{2} \mathrm{C}_{6} \mathrm{H}_{4} \mathrm{SO}_{3}\right)_{3} \cdot 8 \mathrm{H}_{2} \mathrm{O}$ & 26.97 & 27.59 & 4.28 & 4.11 & 5.24 & 5.40 & 12.00 & 12.36 \\
\hline $\mathrm{Nd}\left(\mathrm{NH}_{2} \mathrm{C}_{6} \mathrm{H}_{4} \mathrm{SO}_{3}\right)_{3} \cdot 8 \mathrm{H}_{2} \mathrm{O}$ & 26.86 & 27.29 & 4.26 & 4.09 & 5.22 & 5.46 & 11.95 & 12.39 \\
\hline $\mathrm{Sm}\left(\mathrm{NH}_{2} \mathrm{C}_{6} \mathrm{H}_{4} \mathrm{SO}_{3}\right)_{3} \cdot 8 \mathrm{H}_{2} \mathrm{O}$ & 26.66 & 27.50 & 4.23 & 4.14 & 5.18 & 5.46 & 11.86 & 12.42 \\
\hline $\mathrm{Eu}\left(\mathrm{NH}_{2} \mathrm{C}_{6} \mathrm{H}_{4} \mathrm{SO}_{3}\right)_{3} 8 \mathrm{H}_{2} \mathrm{O}$ & 26.60 & 26.99 & 4.23 & 4.08 & 5.17 & 5.47 & 11.84 & 12.21 \\
\hline $\mathrm{Gd}\left(\mathrm{NH}_{2} \mathrm{C}_{6} \mathrm{H}_{4} \mathrm{SO}_{3}\right)_{3} \cdot 8 \mathrm{H}_{2} \mathrm{O}$ & 26.43 & 26.98 & 4.20 & 4.08 & 5.14 & 5.45 & 11.76 & 12.24 \\
\hline
\end{tabular}


two exothermic peaks at 723 and $843 \mathrm{~K}$. The $\mathrm{La}_{2} \mathrm{O}_{2} \mathrm{SO}_{4}$ is stable up to $1483 \mathrm{~K}{ }^{\circ} \mathrm{C}$ when its decomposition takes place to produce $\mathrm{La}_{2} \mathrm{O}_{3}$. At $1573 \mathrm{~K}$, the final residue is a mixture of $\mathrm{La}_{2} \mathrm{O}_{2} \mathrm{SO}_{4}$ and $\mathrm{La}_{2} \mathrm{O}_{3}$.

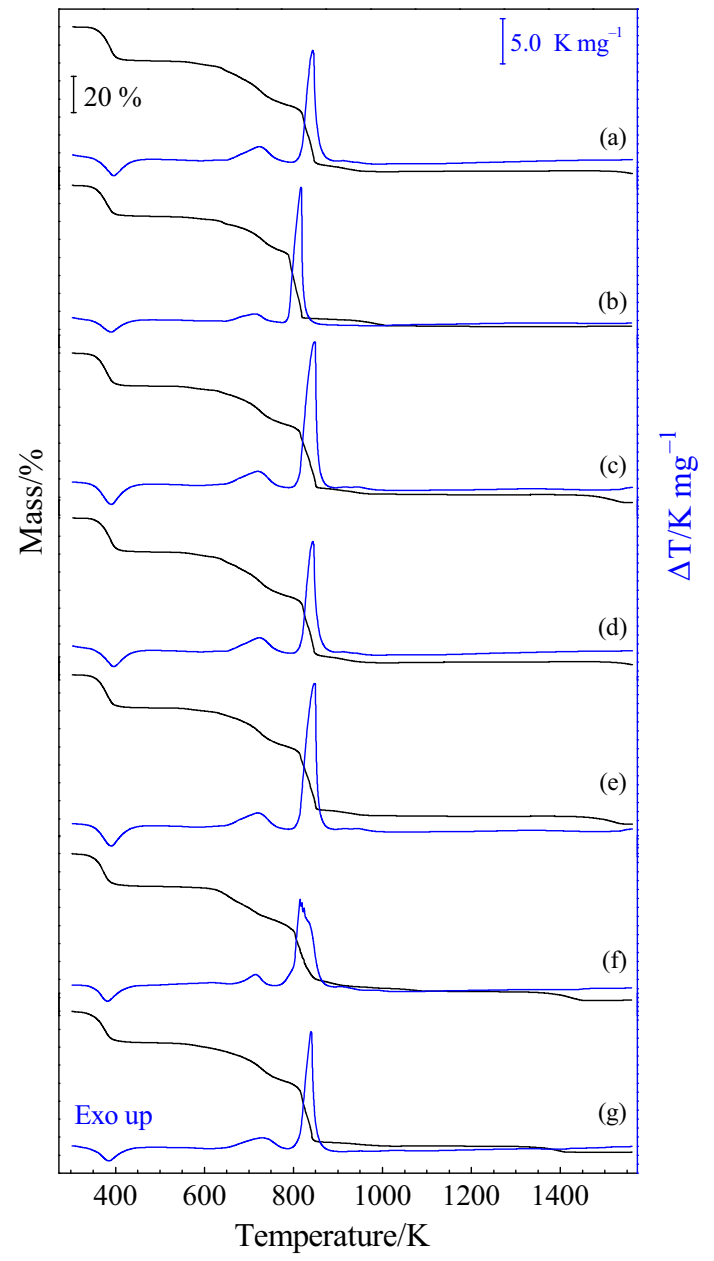

Fig. 3 TG-DTA curves: (a) $\mathrm{LaL}_{3} 8 \mathrm{H}_{2} \mathrm{O}(m=4.304 \mathrm{mg}),(b) \mathrm{CeL}_{3}$ $7 \mathrm{H}_{2} \mathrm{O}(m=3.426 \mathrm{mg}),(c) \mathrm{PrL}_{3} 8 \mathrm{H}_{2} \mathrm{O}(m=5.343 \mathrm{mg}),(d) \mathrm{NdL}_{3}$ $8 \mathrm{H}_{2} \mathrm{O}(m=4.299 \mathrm{mg})$, (e) $\mathrm{SmL}_{3} 8 \mathrm{H}_{2} \mathrm{O}(m=5.342 \mathrm{mg})$, (f) $\mathrm{EuL}_{3}$ $8 \mathrm{H}_{2} \mathrm{O}(m=4.207 \mathrm{mg})$ and $(\mathrm{g}) \mathrm{GdL}_{3} 8 \mathrm{H}_{2} \mathrm{O}(m=4.005 \mathrm{mg})$

\section{$\mathrm{Ce}\left(\mathrm{NH}_{2} \mathrm{C}_{6} \mathrm{H}_{4} \mathrm{SO}_{3}\right)_{3} \cdot 7 \mathrm{H}_{2} \mathrm{O}$}

The TG-DTA curves are shown in Fig. 3b. The dehydration occurs between 325 and $441 \mathrm{~K}$, with mass loss of $16.8 \%\left(\simeq 7 \mathrm{H}_{2} \mathrm{O}\right)$ characterized by an endothermic peak in DTA curve at $390 \mathrm{~K}$, as can be seen in Fig. 3b. From DSC data, this event was evaluated with dehydration enthalpy of $495 \mathrm{~kJ} \mathrm{~mol}^{-1}$ (Fig. 4) and the anhydrous compound remains stable up to $809 \mathrm{~K}$. The thermal decomposition of organic material occurs between 536 and $1013 \mathrm{~K}$, with the formation of the respective oxide $\mathrm{CeO}_{2}$ (Fig. 5). Two exothermic peaks are observed in DTA and DSC curves for

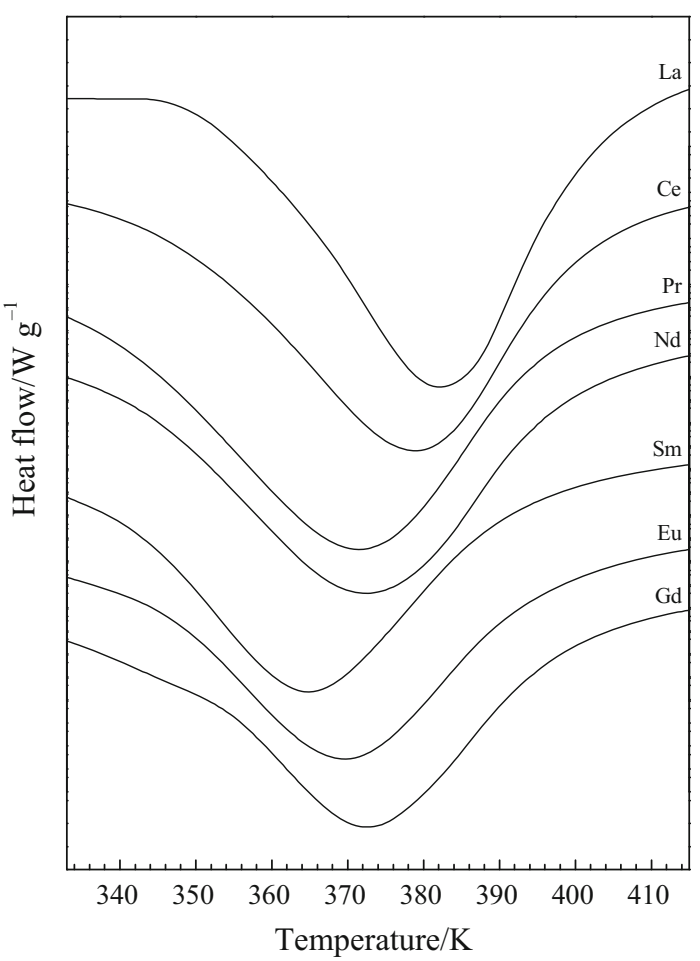

Fig. 4 DSC curves of all compounds showing the dehydration step

Table 2 Thermal analytical data from TG, DTA and DSC curves

\begin{tabular}{|c|c|c|c|c|c|c|c|c|c|c|c|}
\hline \multirow[t]{2}{*}{ Sample } & \multicolumn{2}{|c|}{ M.M./g mol ${ }^{-1}$} & \multicolumn{2}{|c|}{$\% \mathrm{H}_{2} \mathrm{O}$} & \multirow{2}{*}{$\begin{array}{l}\Delta H_{(\mathrm{dehydr})} \\
\mathrm{kJ} \mathrm{mol}^{-1}\end{array}$} & \multicolumn{2}{|c|}{$\%$ metal } & \multicolumn{2}{|c|}{$\% \mathrm{Ln}_{2} \mathrm{O}_{2} \mathrm{SO}_{4}$} & \multicolumn{2}{|c|}{$\%$ residue } \\
\hline & Calc. & TG & Calc. & TG & & Calc. & TG & Calc. & TG & Calc. & TG \\
\hline $\mathrm{LaL}_{3} \cdot 8 \mathrm{H}_{2} \mathrm{O}$ & 799.53 & 806.71 & 18.02 & 18.75 & 539 & 17.37 & 17.22 & 25.38 & 23.38 & 20.38 & $19.56^{*}$ \\
\hline $\mathrm{CeL}_{3} \cdot 7 \mathrm{H}_{2} \mathrm{O}$ & 782.73 & 789.35 & 16.11 & 16.81 & 495 & 17.90 & 17.75 & - & - & 21.99 & 22.50 \\
\hline $\mathrm{PrL}_{3} \cdot 8 \mathrm{H}_{2} \mathrm{O}$ & 801.53 & 805.99 & 17.98 & 18.43 & 536 & 17.58 & 17.48 & 25.57 & 25.58 & 21.23 & $16.97^{*}$ \\
\hline $\mathrm{NdL}_{3} \cdot 8 \mathrm{H}_{2} \mathrm{O}$ & 804.86 & 814.37 & 17.90 & 18.86 & 524 & 17.92 & 17.71 & 25.88 & 23.78 & 20.90 & $18.84^{*}$ \\
\hline $\mathrm{SmL}_{3} \cdot 8 \mathrm{H}_{2} \mathrm{O}$ & 810.99 & 816.19 & 17.77 & 18.29 & 431 & 18.55 & 18.43 & 26.43 & 25.16 & 21.46 & 21.33 \\
\hline $\mathrm{EuL}_{3} \cdot 8 \mathrm{H}_{2} \mathrm{O}$ & 812.59 & 816.51 & 17.73 & 18.14 & 420 & 18.71 & 18.06 & 26.58 & 23.39 & 21.66 & 21.55 \\
\hline $\mathrm{GdL}_{3} \cdot 8 \mathrm{H}_{2} \mathrm{O}$ & 817.88 & 810.34 & 17.61 & 16.85 & 412 & 19.26 & 19.41 & 27.06 & 25.44 & 22.16 & 22.37 \\
\hline
\end{tabular}

M.M. molar mass

* Incomplete decomposition up to $1573 \mathrm{~K}$ 


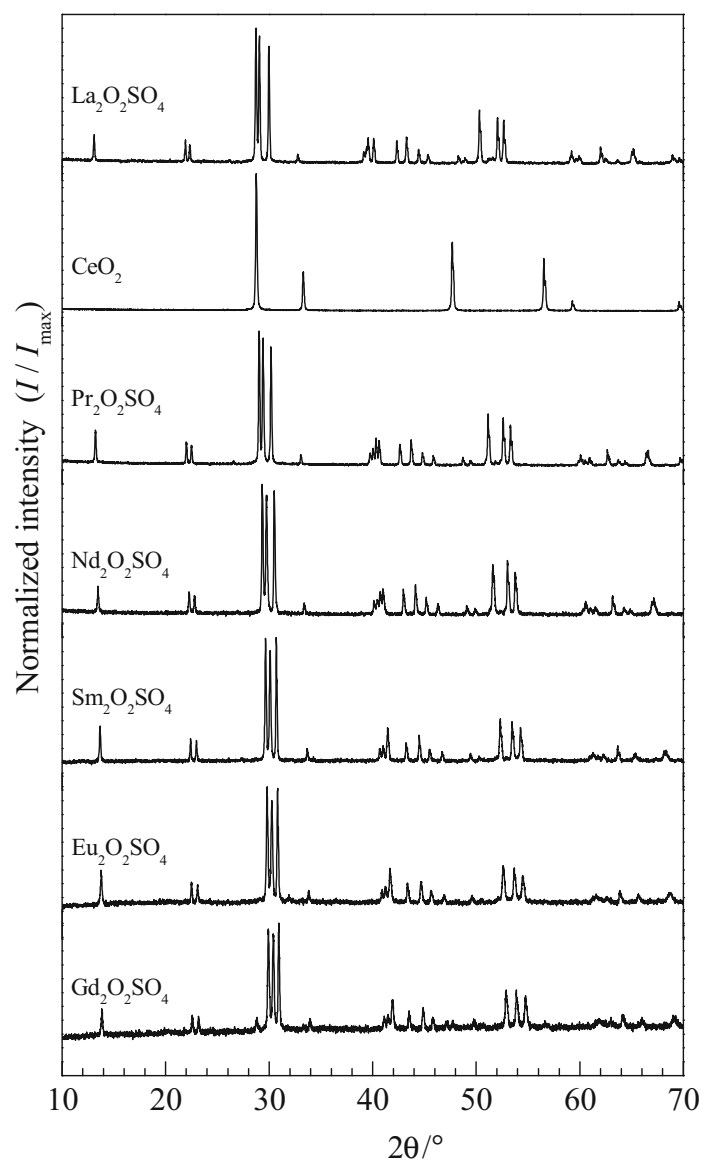

Fig. 5 X-ray diffraction pattern of the samples after heating at $1273 \mathrm{~K}$ for $2 \mathrm{~h}$ in a muffle furnace

this step, the first one at $714 \mathrm{~K}$ and another at $817 \mathrm{~K}$. There was no observed stable intermediate for this compound.

\section{$\operatorname{Pr}\left(\mathrm{NH}_{2} \mathrm{C}_{6} \mathrm{H}_{4} \mathrm{SO}_{3}\right)_{3} \cdot \mathbf{8 \mathrm { H } _ { 2 } \mathrm { O }}$}

The TG-DTA curves are shown in Fig. 3c. The dehydration process occurs in the range of $313-447 \mathrm{~K}$ with mass loss of $18.4 \%$, attributed to dehydration $\left(\simeq 8 \mathrm{H}_{2} \mathrm{O}\right)$ associated with an endothermic peak in DTA curve at $390 \mathrm{~K}$. In the DSC analysis, the enthalpy was evaluated around $536 \mathrm{~kJ} \mathrm{~mol}^{-1}$ (Fig. 4). The anhydrous compound is stable up to $517 \mathrm{~K}$ and after this temperature, the thermal decomposition of the sulfanilate ligand takes place between 517 and $991 \mathrm{~K}$, producing a stable intermediate $\mathrm{Pr}_{2} \mathrm{O}_{2} \mathrm{SO}_{4}$ (Fig. 5), associated with exothermic peaks at 721 and $846 \mathrm{~K}$ in both DTA and DSC curves. The last event is the partial thermal decomposition of $\mathrm{Pr}_{2} \mathrm{O}_{2} \mathrm{SO}_{4}$ to $\mathrm{Pr}_{6} \mathrm{O}_{11}$ above $1553 \mathrm{~K}$. At $1573 \mathrm{~K}$, the final residue is a mixture of $\mathrm{Pr}_{2} \mathrm{O}_{2} \mathrm{SO}_{4}$ and $\operatorname{Pr}_{6} \mathrm{O}_{11}$.
$\mathrm{Nd}\left(\mathrm{NH}_{2} \mathrm{C}_{6} \mathrm{H}_{4} \mathrm{SO}_{3}\right)_{3} \cdot 8 \mathrm{H}_{2} \mathrm{O}$

The TG-DTA curves are shown in Fig. 3d. As can be noted, the initial mass loss of $18.6 \%$ is in agreement with the release of eight water molecules and this event was associated with an endothermic peak in DTA and DSC curves $(397 \mathrm{~K})$. The dehydration enthalpy found for this compound was $524 \mathrm{~kJ} \mathrm{~mol}^{-1}$ (Fig. 4) in the DSC analysis. The anhydrous compound is stable up to $529 \mathrm{~K}$ and the thermal decomposition of organic material takes place between 529 and $1033 \mathrm{~K}$, with exothermic peaks in DTA and DSC curves at 723 and $843 \mathrm{~K}$, respectively. The $\mathrm{Nd}_{2} \mathrm{O}_{2} \mathrm{SO}_{4}$ (Fig. 5) was obtained as a stable intermediate between 1033 and $1473 \mathrm{~K}$, and after this temperature, its decomposition takes place producing a mixture of $\mathrm{Nd}_{2} \mathrm{O}_{2}$ $\mathrm{SO}_{4}$ and $\mathrm{Nd}_{2} \mathrm{O}_{3}$ as final residue at $1573 \mathrm{~K}$.

\section{$\mathrm{Sm}\left(\mathrm{NH}_{2} \mathrm{C}_{6} \mathrm{H}_{4} \mathrm{SO}_{3}\right)_{3} \cdot 8 \mathrm{H}_{2} \mathrm{O}$}

The TG-DTA curves are shown in Fig. 3e. The initial mass loss of $18.3 \%\left(8 \mathrm{H}_{2} \mathrm{O}\right)$ is characterized by an endothermic peak $\left(T_{\text {peak }}=391 \mathrm{~K}\right)$ in the DTA curve and an enthalpy of $431 \mathrm{~kJ} \mathrm{~mol}^{-1}$ in the DSC curve (Fig. 4). The anhydrous compound is stable between 440 and $515 \mathrm{~K}$, and the thermal decomposition of organic contents occurs in the range of 515 and $991 \mathrm{~K}$, where $\mathrm{Sm}_{2} \mathrm{O}_{2} \mathrm{SO}_{4}$ is produced (Fig. 5). In this last step, two exothermic peaks at 721 and $849 \mathrm{~K}$ are observed. The stable intermediate starts its decomposition only in higher temperature than $1553 \mathrm{~K}$ producing the samarium oxide as a final residue.

\section{$\mathrm{Eu}\left(\mathrm{NH}_{2} \mathrm{C}_{6} \mathrm{H}_{4} \mathrm{SO}_{3}\right)_{3} \cdot 8 \mathrm{H}_{2} \mathrm{O}$}

The TG-DTA curves are shown in Fig. 3f. The initial mass loss of $18.1 \%\left(8 \mathrm{H}_{2} \mathrm{O}\right)$ is characterized by an endothermic peak at $387 \mathrm{~K}$, and the dehydration enthalpy of $420 \mathrm{~kJ} \mathrm{~mol}^{-1}$ was evaluated by means of DSC analysis (Fig. 4). The anhydrous compound is stable up to $573 \mathrm{~K}$ where the second event of mass loss takes place until $1111 \mathrm{~K}$ with two exothermic peaks at 716 and $814 \mathrm{~K}$, producing the $\mathrm{Eu}_{2} \mathrm{O}_{2} \mathrm{SO}_{4}$ (Fig. 5) as a stable intermediate. The $\mathrm{Eu}_{2} \mathrm{O}_{2} \mathrm{SO}_{4}$ is stable until $1314 \mathrm{~K}$, and after this temperature the europium oxide is obtained as a final residue from $1453 \mathrm{~K}$.

\section{$\mathrm{Gd}\left(\mathrm{NH}_{2} \mathrm{C}_{6} \mathrm{H}_{4} \mathrm{SO}_{3}\right)_{3} \cdot 8 \mathrm{H}_{2} \mathrm{O}$}

The TG-DTA curves are shown in Fig. 3g. For this sample, the dehydration process occurs with an initial mass loss of $16.9 \%$ corresponding to eight water molecules released and an endothermic peak at $383 \mathrm{~K}$ in DTA curve. The dehydration enthalpy was evaluated in $412 \mathrm{~kJ} \mathrm{~mol}^{-1}$ in the DSC analysis (Fig. 4). The anhydrous compound is 
stable up to $526 \mathrm{~K}$, and above this temperature the decomposition of organic material occurs up to $1037 \mathrm{~K}$, showing two exothermic peaks associated with this event at 728 and $821 \mathrm{~K}$ in DTA curve. The decomposition of organic material produces the $\mathrm{Gd}_{2} \mathrm{O}_{2} \mathrm{SO}_{4}$ (Fig. 5) that is stable until $1311 \mathrm{~K}$ where the gadolinium oxide is formed as a final residue at $1423 \mathrm{~K}$.

These results indicate that the thermal stability of the compound decreases for the lanthanide ions with lower ionic radius.

From the TG-DTA data, it was possible to establish a general formula to the compound as $\mathrm{LnL}_{3} \cdot n \mathrm{H}_{2} \mathrm{O}$, where $\mathrm{Ln}$ represents trivalent lanthanide ions $(\mathrm{La}, \mathrm{Ce}, \mathrm{Pr}, \mathrm{Nd}, \mathrm{Sm}, \mathrm{Eu}$ and $\mathrm{Gd}), \mathrm{L}$ is 4-amino-benzenesulfonate anion $\left(\mathrm{NH}_{2} \mathrm{C}_{6}\right.$ $\left.\mathrm{H}_{4} \mathrm{SO}_{3}^{-}\right)$and $n=7(\mathrm{Ce})$ and $8(\mathrm{La}, \mathrm{Pr}, \mathrm{Nd}, \mathrm{Sm}, \mathrm{Eu}$ and $\mathrm{Gd})$. The DTA curves show that organic material decomposition $\left(\mathrm{NH}_{2} \mathrm{C}_{6} \mathrm{H}_{4} \mathrm{SO}_{3}{ }^{-}\right)$occurred in consecutive steps with, at least, two or three exothermic peaks, related to release of $\mathrm{CO}_{2}, \mathrm{H}_{2} \mathrm{O}$ and $\mathrm{SO}_{3}$ gases.

When heated at $1273 \mathrm{~K}$ for $2 \mathrm{~h}$ in a muffle furnace, the compounds formed the respective dioxysulfates $\left(\mathrm{Ln}_{2} \mathrm{O}_{2}\right.$ $\mathrm{SO}_{4}$ ). The formation of a stable intermediate, $\mathrm{Ln}_{2} \mathrm{O}_{2} \mathrm{SO}_{4}$, during the thermal decomposition of these compounds based on the TG-DTA curves was confirmed by comparison with the diffraction pattern for $\mathrm{La}_{2} \mathrm{O}_{2} \mathrm{SO}_{4}$ (JCPDF No. 01-085-1534), as can be seen in Fig. 5. All dioxysulfates obtained are isomorphic. For cerium, the formation of $\mathrm{CeO}_{2}$ was also confirmed.

\section{Conclusions}

The infrared spectroscopic data indicate that the trivalent coordination of lanthanide ions occurs through the sulfonic group and the bands observed were associated with the stretches $\left(v \mathrm{O}-\mathrm{H}, v \mathrm{~N}-\mathrm{H}\right.$ and $\left.v \mathrm{SO}_{3}\right)$ and deformations $(\delta$ $\mathrm{H}-\mathrm{S}-\mathrm{H}$ and $\delta \mathrm{H}-\mathrm{C}-\mathrm{H})$. The $\mathrm{X}$-ray powder diffraction suggests that the compounds are crystalline and the formation of an isomorphic series. TG-DTA analysis provided previously unreported information concerning the thermal behavior and thermal decomposition of these compounds, and based on the TG curves, a general formula could be established for the synthesized compounds: $\mathrm{LnL}_{3} \cdot \mathrm{nH}_{2} \mathrm{O}$, where $\mathrm{Ln}=(\mathrm{La}, \mathrm{Ce}, \mathrm{Pr}, \mathrm{Nd}, \mathrm{Sm}, \mathrm{Eu}$ and $\mathrm{Gd}$ ); $\mathrm{L}=\left(\mathrm{NH}_{2} \mathrm{C}_{6} \mathrm{H}_{4} \mathrm{SO}_{3}^{-}\right)$and $n=7$ for $\mathrm{Ce}^{3+}$ and 8 for $\left(\mathrm{La}^{3+}\right.$, $\mathrm{Pr}^{3+}, \mathrm{Nd}^{3+}, \mathrm{Sm}^{3+}, \mathrm{Eu}^{3+}$ and $\left.\mathrm{Gd}^{3+}\right)$. The dehydration process occurs in a single step up to $453 \mathrm{~K}$ and the enthalpy of dehydration decreases from $\mathrm{La}^{3+}$ to $\mathrm{Gd}^{3+}$ as a consequence of the decrease in the ionic radius of the lanthanide ion. The thermal decomposition of all compounds, except cerium, presented in its thermal pathway a stable intermediate $\mathrm{Ln}_{2} \mathrm{O}_{2} \mathrm{SO}_{4}$, which subsequently decompose to their respective oxides. For the $\mathrm{La}^{3+}, \mathrm{Pr}^{3+}$ and $\mathrm{Nd}^{3+}$ sulfanilates, the formation of residual oxide occurs above $1573 \mathrm{~K}$ and in the present work it was obtained as a mixture. The formation of $\mathrm{Ln}_{2} \mathrm{O}_{2} \mathrm{SO}_{4}$ was verified by $\mathrm{X}$-ray diffraction after heating at $1273 \mathrm{~K}$ for $2 \mathrm{~h}$.

Acknowledgements This research was supported by resources supplied by the Faculdade de Engenharia de Guaratinguetá (UNESP). The authors thank Prof. Dr. Ivonete Ávila (DEN-FEG-UNESP) and Luiz Carlos Rios for TG-DTA measurements, Prof. Dr. Jivaldo O. Matos (IQ-USP) and the Laboratório de Engenharia e Controle Ambiental-LENCA for the elemental analysis, Prof. Dr. Luiz Rogério de Oliveira Hein (DMT-FEG-UNESP) for X-ray diffractometry, Prof. Dr. Konstantin Georgiev Kostov (DFQ-FEG-UNESP) for FTIR measurements and Willian Capelupi, Bachelor and Chemistry graduate, application specialist at TA Instruments, for DSC measurements.

\section{References}

1. Moss GP, Smith PAS, Tavernier D. Glossary of class names of organic compounds and reactive intermediates based on structure. Pure Appl Chem. 1995;67:1307-75.

2. Moeller T. The chemistry of the lanthanides. New York: Reinhold Publishing Corporation; 1963.

3. Gunderman BJ, Squattrito PJ. Structural variations in layered alkali metal naphthalenesulfonates. Inorg Chem. 1995;34:2399-406.

4. Kosnic EJ, McClymont EL, Holder RA, Squattrito PJ. Synthesis and structures of layered metal sulfonate salts. Inorg Chim Acta. 1992;201:143-51.

5. Shubnell AJ, Kosnic RJ, Squattrito PJ. Structure of layered metal sulfonate salts: trend in coordination behavior of alkali, alkaline earth and transition metals. Inorg Chim Acta. 1994;216:101-12.

6. Gunderman BJ, Squattrito PJ. Synthesis and structures of potassium and rubidium arenesulfonates. Inorg Chem. 1994;33:2924-31.

7. Gunderman BJ, Squattrito PJ, Dubey SN. Copper and manganese sulfanilate hydrates. Acta Crystallogr Sect C. 1996;52:1131-4.

8. Vinciguerra A, Plavidal JF, Prados RA Jr, Zimmerman RL Jr. Preparation, magnetic moments, infrared and optical spectra of ortho-, meta-, and para-aminobenzenesulfonate copper(II) complexes. J Inorg Nucl Chem. 1969;31:1061-7.

9. Shakeri V, Haussühl S. Crystal structure of cobalt of sulfanilate tetrahydrate, $\left(\mathrm{Co}\left(\mathrm{NH}_{2} \mathrm{C}_{6} \mathrm{H}_{4} \mathrm{SO}_{3}\right)_{2}\left(\mathrm{H}_{2} \mathrm{O}\right)_{4} . \quad \mathrm{Z} \quad\right.$ Kristallogr. 1992;198:165-6.

10. Sharma RP, Sing A, Aree T, Venugopalan P. Cationic cobalt(III) complex as anion receptor: synthesis, spectroscopic characterization, single-crystal $\mathrm{X}$-ray structure determination and packing analysis of $\left[\mathrm{Co}(\text { phen })_{2} \mathrm{CO}_{3}\left[(4-\right.\right.$ aminobenzenesulfonate $) \cdot 6 \mathrm{H}_{2} \mathrm{O}$. J Mol Struct. 2009;928:18-24.

11. Starynowicz P. Structure of bis(4-aminobenzenesulfonateO)heptaaquaneodymium 4-aminobenzenesulfonate hydrate. Acta Crystallogr Sect C. 1992;48:1414-6.

12. Zhao Y, Sum B, Xu Y, Wang D, Weng S, Wu J, Xu D, Xu G. FTIR study of 4-aminobenzenesulfonate complexes. J. Mol. Struct. 2001;560:115-20. 